\title{
Artikel
}

\section{Het nemo-teneturbeginsel bij digitale opsporingsbevoegdheden: oproep tot discussie over fundamentele bezinning van de normering van het opsporingsonderzoek in een digitale context}

\author{
D.A.G. van Toor PhD LLM BSc*
}

\section{Inleiding}

Een van de redenen die de wetgever noemt als grond voor de modernisering van het Wetboek van Strafvordering is dat de 'laatste decennia tal van technieken beschikbaar [zijn] gekomen die van invloed zijn op de wijze waarop de strafvordering plaatsvindt. Die invloed is bijvoorbeeld zichtbaar in de wijze waarop de opsporing plaatsvindt.' ${ }^{1}$ Het gaat hierbij niet alleen om herstructurering (zoals bij de Wet Bijzondere opsporingsbevoegdheden) ${ }^{2}$ of codificatie (zoals bij de doorbreking van het verschoningsrecht bij verdachte verschoningsgerechtigden $)^{3}$, maar om een fundamentele bezinning die moet zorgen voor een snelle en wendbare opspo-

* D.A.G. van Toor PhD LLM BSc is verbonden als universitair docent aan het Willem Pompe Instituut voor Strafrechtswetenschappen en het Montaigne Centrum voor Rechtsstaat en Rechtspleging van de Universiteit Utrecht. Dit artikel is op 8 januari 2021 ingediend. Het recente arrest van de HR (9 februari 2021, ECLI:NL:HR:2021:202) is derhalve niet meegenomen in deze bijdrage.

1. Memorie van Toelichting: Vaststellingswet Boek 1 van het nieuwe Wetboek van Strafvordering (consultatieversie), p. 13.

2. Memorie van Toelichting: Vaststellingswet Boek 1 van het nieuwe Wetboek van Strafvordering (consultatieversie), p. 9

3. Memorie van Toelichting: Vaststellingswet Boek 1 van het nieuwe Wetboek van Strafvordering (consultatieversie), p. 77. ring. ${ }^{4}$ Om tot 'een meer fundamentele bezinning op de regeling van het opsporingsonderzoek in een digitale context' te komen, heeft de Commissie modernisering opsporingsonderzoek in het digitale tijdperk (hierna: de Commissie) het eerste conceptwetsvoorstel geanalyseerd. ${ }^{5}$ Op basis van het advies van de Commissie is de laatste versie van Boek 2 - waarin de opsporingsbevoegdheden in het nieuwe wetboek worden opgenomen - tot stand gekomen. ${ }^{6}$

Tot een fundamentele bezinning op de normering van het opsporingsonderzoek in een digitale context heeft een en ander niet geleid. De Commissie en de wetgever gebruiken de bestaande rechtsbeschermende waarborgen voor de normering van de (nieuwe) digitale bevoegdheden. Een van de aandachtspunten die zowel de Commissie als wetgever hierbij in acht neemt, is het nemo-teneturbeginsel. In het advies van de Commissie

4. Commissie modernisering opsporingsonderzoek in het digitale tijdperk Regulering van opsporingsbevoegdheden in een digitale omgeving, s.l. 2018, p. 7.

5. Commissie modernisering opsporingsonderzoek in het digitale tijdperk, Regulering van opsporingsbevoegdheden in een digitale omgeving, s.l. 2018, p. 6.

6. Brief van de Minister van Justitie en Veiligheid aan de Tweede Kamer, zie www.rijksoverheid.nl/documenten/brieven/2018/10/04/briefconsultatie-boek-2-onderdeel-opsporing-in-een-digitale-omgeving, laatst geraadpleegd op 26 november 2020. Zie ook de actuele versie van het conceptwetsvoorstel: www.rijksoverheid.nl/documenten/ publicaties/2019/02/07/concept-wetsvoorstel-en-mvt-boek-2onderdeel-opsporing-in-een-digitale-omgeving. 
wordt getoetst of aan de verdachte een bevel kan worden gegeven om zijn elektronische gegevensdragers met een biometrisch kenmerk te ontgrendelen. ${ }^{7}$ Deze discussie speelt in de rechtswetenschap en de rechtspraktijk, in binnen- en buitenland, al langer, maar van een wettelijke basis was nog geen sprake. ${ }^{8}$ In de literatuur is de duidelijke meerderheidsopvatting, ${ }^{9}$ die in 2017 voor het eerst werd ingestoken, ${ }^{10}$ dat de verdachte verplicht kan worden elektronische gegevensdragers met een biometrisch kenmerk te ontgrendelen, maar dat van een verplichting zijn wachtwoord af te staan geen sprake kan zijn. ${ }^{11}$ Verschillende nationale gerechten hebben dezelfde conclusie getrokken. ${ }^{12}$ Ondanks de duidelijke meerderheidsopvatting werd tegen een van de eerste uitspraken, een vonnis van de rechtbank Noord-Holland, ${ }^{13}$ cassatie in het belang van de wet ingesteld waarin advocaat-generaal Bleichrodt onlangs concludeerde. ${ }^{14}$

\subsection{Probleemschets}

In deze bijdrage bespreek ik de zojuist genoemde conclusie, in het licht van de afwezigheid van een fundamentele bezinning op de normering van opsporingsbevoegdheden in de digitale wereld. Bleichrodt onderschrijft het oordeel van de rechtbank dat de verdachte gedwongen kan worden zijn elektronische gegevensdrager met een biometrisch kenmerk te ontgrendelen, mits de toegepaste dwang slechts een lichte inbreuk op de lichamelijke integriteit vormt. ${ }^{15}$ Dit is in lijn met de eerdergenoemde meerderheidsopvatting. Deze analyse van het positieve recht is nog steeds overtuigend. Bleichrodt gebruikt - net als de Commissie - de standaardrecht-

7. Commissie modernisering opsporingsonderzoek in het digitale tijdperk, Regulering van opsporingsbevoegdheden in een digitale omgeving, s.l. 2018, p. 105 e.v.

8. D.A.G. van Toor, 'De vergrendelde smartphone als object van strafvorderlijk onderzoek', Computerrecht 2017, 1, p. 3-11; D.A.G. van Toor, 'Het gedwongen ontgrendelen van een smartphone in het licht van het nemo-teneturbeginsel. Reactie op Boods "Geef ze een vinger ..."', NJB 2019, 317; L. Stevens, 'Gedwongen biometrische toegangsverschaffing is niet in strijd met nemo tenetur', NJB 2019, 315; M. Egberts \& W. Ferdinandusse, 'Reactie op Alex Bood', NJB 2019, 316; D.A.G van Toor, W. Albers, C.M. Taylor Parkins-Ozephius \& T. Beekhuis, 'De ontgrendelplicht in rechtsvergelijkend perspectief (deel 1)', Computerrecht 2020/131; T. Beekhuis, C.M. Taylor Parkins-Ozephius, D.A.G. van Toor $\&$ W. Albers, 'De ontgrendelplicht in rechtsvergelijkend perspectief (deel 2)', Computerrecht 2020/179; W. Albers, T. Beekhuis en C.M. Taylor Parkins-Ozephius, 'Geef mij toegang tot uw smartphone! Een zoektocht naar de wettelijke grondslag van de gedwongen biometrische ontgrendeling van de smartphone', TBS\&H 2019, 3, p. 173-181.

9. Anders A. Bood, 'Geef ze een vinger ...', NJB 2018, 36, p. 2744-2748.

10. D.A.G. van Toor, 'De vergrendelde smartphone als object van strafvorderlijk onderzoek', Computerrecht 2017, 1, p. 3-11.

11. D.A.G. van Toor, 'Het gedwongen ontgrendelen van een smartphone in het licht van het nemo-teneturbeginsel. Reactie op Boods "Geef ze een vinger ..."', NJB 2019, 317; M. Egberts \& W. Ferdinandusse, 'Reactie op Alex Bood', NJB 2019, 316; L. Stevens, 'Gedwongen biometrische toegangsverschaffing is niet in strijd met nemo tenetur', NJB 2019, 315.

12. Rb. Den Haag 12 maart 2018, ECLI:NL:RBDHA:2018:2983; Rb. Rotterdam 14 december 2018, ECLI:NL:RBROT:2018:10283; Rb. Noord-Holland 28 februari 2019, ECLI:NL:RBNHO:2019:1568, Computerrecht 2019/94, m.nt. D.A.G. van Toor.

13. Rb. Noord-Holland 28 februari 2019, ECLI:NL:RBNHO:2019:1568, Computerrecht 2019/94, m.nt. D.A.G. van Toor

14. Conclusie F.W. Bleichrodt, 13 oktober 2020, ECLI:NL:PHR:2020:927.

15. Conclusie F.W. Bleichrodt, 13 oktober 2020, ECLI:NL:PHR:2020:927, rn. 47-54. spraak over het nemo-teneturbeginsel als rechtsbeschermende waarborg. Toch zie ik grond om de meerderheidsopvatting - en daarmee dus ook mijn eerdere conclusie, noem het voortschrijdend inzicht - en Bleichrodts conclusie te problematiseren.

Centraal in de meerderheidsopvatting staat de normering van opsporingsbevoegdheden via het criterium de aard en mate van dmang. Bij het ontgrendelen is slechts sprake van een lichte inbreuk op de lichamelijke integriteit, namelijk het beperken van de bewegingsvrijheid van de hand en, vervolgens, het op de scanner leggen van de vinger of duim van de verdachte. Omdat deze inbreuk als licht moet worden gecategoriseerd en de verdachte een bepaalde mate van dwang moet dulden, is geen sprake van een schending van het verbod op gedwongen zelfincriminatie.

De criteria die zijn ontwikkeld om te beoordelen of de gebruikte dwang de zelfincriminerende positie van de verdachte ongeoorloofd aantast, zijn echter decennia oud. Zij zijn ontwikkeld in tijden waarin de overheid grove fysieke dwang toepaste - denk aan schendingen van het folterverbod - en hoge (vrijheidsbenemende) sancties op niet-meewerken konden volgen, maar tijden veranderen. Tegenwoordig is de mate van dwang licht, terwijl de hoeveelheid informatie die wordt verkregen exponentieel is toegenomen. Gezien het feit dat geringe dwang - het begrenzen van de beweeglijkheid van de pols en de hand en het vervolgens scannen van de vingerafdruk - giga- of terabytes aan informatie oplevert, moet worden nagedacht of de criteria waaronder klachten over schending van het nemo-teneturbeginsel worden beoordeeld aanpassing behoeven. Het toetsingskader waarin de aard en mate van dmang een noodzakelijke schakel vormen voor een geslaagd beroep op schending van het nemo-teneturbeginsel lijkt niet meer van deze tijd. Met andere woorden, niet alleen het opsporingsarsenaal, maar ook de rechtsbeschermende waarborgen verdienen een fundamentele bezinning. ${ }^{16}$ Deze bijdrage is het startpunt van die fundamentele bezinning. ${ }^{17}$

\subsection{Leeswijzer}

Om de noodzaak tot aanpassing van de criteria duidelijk te maken, wordt de zaak die bij de rechtbank NoordHolland speelde, en waartegen cassatie in het belang der wet is ingediend, vergeleken met Falloh t. Duitsland. ${ }^{18}$ Kort gezegd, zijn deze twee zaken volledig asymmetrisch als het gaat om de beoordeling van de nemoteneturklacht. Dit wordt uitgewerkt in paragraaf 2. In paragraaf 3 volgt een intermezzo naar het Amerikaanse constitutionele recht, waarin dezelfde discussie - in hoe-

16. Denkend aan het boek Instrumentaliteit en rechtsbescherming (R. Foqué \& A.C. 't Hart, Instrumentaliteit en rechtsbescherming. Grondslagen van een strafrechtelijke waardendiscussie, Arnhem: Gouda Quint 1990) zou eigenlijk elke instrumentele fundamentele bezinning moeten worden vergezeld door een rechtsbeschermende fundamentele bezinning.

17. Nog meer dan anders kijk ik uit naar reacties.

18. EHRM 11 juli 2006, appl. no. 54810/00 (Jalloh t. Duitsland). 
verre beschermt een grondrecht (het Vierde Amendement) de toepassing van technologische uitvindingen met een strafrechtelijk doel? - telkens speelt als de autoriteiten technologische ontwikkelingen inzetten in opsporingsonderzoeken. Op basis van die beschrijving volgt (eens temeer) dat het toepassen van aloude criteria op nieuwe situaties tot ongewenste uitkomsten leidt. Overigens bestaat ook een tweede grond om een uitstapje te wagen naar het Amerikaanse recht. Het Vierde Amendement bij de Amerikaanse Grondwet is te vergelijken met het nemo-teneturbeginsel: beide bieden bescherming tegen ongeoorloofde opsporingshandelingen waarmee geen testimonial bewijs wordt verkregen.

Vervolgens staan in paragraaf 4 meerdere zienswijzen centraal van de bescherming die het nemo-teneturbeginsel kan bieden, te weten (1) bescherming tegen het gebruik van ongeoorloofde dmang; (2) bescherming tegen een bepaalde vorm van medemerking; (3) bescherming tegen het gebruik van onder dwang verkregen informatie; en (4) bescherming tegen het wilsafhankelijk verkrijgen van informatie. Wat het nemo-teneturbeginsel precies omvat als te beschermen gebied is, zoals uit die paragraaf zal blijken, voer voor discussie, al gaat het vooral om accentverschillen. Uit de verschillende perspectieven blijkt dat de bron/oorsprong/aard (van de verkrijging) van de informatie - bestaat de informatie afhankelijk van de wil van de verdachte c.q. kan de informatie onafhankelijk van de wil van verdachte worden verkregen? - wel van invloed is op de beoordeling van klachten over de schending van het nemo-teneturbeginsel, maar de hoeveelheid verkregen informatie en de inhoud van de informatie niet. Juist die twee punten verschillen in 'moderne' nemo-teneturzaken ten opzichte van de 'traditionele' zaken. In paragraaf 5 stel ik, anders dan uit het geldende positieve recht volgt, voor dat niet langer de aard en mate van dwang centraal zouden moeten staan, ${ }^{19}$ maar dat een meer holistische benadering - wat wordt allemaal verkregen op basis van welke gedraging(en) van de autoriteiten? - noodzakelijk is om van effectieve rechtsbescherming onder het nemoteneturbeginsel te spreken.

\section{Van het verkrijgen van weinig (maar doorslaggevend) bewijs onder grove dwang naar het verkrijgen van veel (maar volledig ongesorteerd) bewijs onder lichte dwang}

Zoals in de inleiding is aangestipt, zijn de criteria waarmee het EHRM nemo-teneturklachten beoordeelt enkele decennia oud. De eerste landmark case is de zaak Saunders van 1997, waaruit, kort gezegd, de conclusie wordt getrokken dat (1) bewijs dat afhankelijk van de wil bestaat, waarvoor een bewuste spierbeweging noodzakelijk is, vanaf lichte dwang bescherming geniet en dat (2) materiaal dat onafhankelijk van de wil bestaat, waarover een mens met enkel zijn wil of zijn gedachten geen controle heeft, onder bepaalde aard en mate van dwang mag worden verkregen. ${ }^{20}$ Uit latere EHRMrechtspraak, onder andere falloh (2006) en Ibrahim en anderen (2016), wordt duidelijk dat het EHRM een drietal criteria gebruikt om te toetsen of een bepaalde overheidshandeling het nemo-teneturbeginsel schendt. Dit zijn: (1) de aard en mate van dmang die werd gebruikt om het bewijs te verkrijgen; (2) relevante maarborgen in de procedure waardoor de mate van dwang wordt gemitigeerd; en (3) de manier waarop het verkregen bewijs wordt gebruikt. ${ }^{21}$ Omdat de aard en mate van dwang centraal staan bij de toetsing wordt van een means-based perspectief gesproken: het nemo-teneturbeginsel beschermt de verdachte tegen ongeoorloofde middelen (terwijl het zwijgrecht bescherming biedt tegen de ongeoorloofde verkrijging van een bepaald bemijsmiddel (material-based)).

In de hierboven genoemde zaken ging het om de verkrijging van real evidence (in het geval van Jalloh: drugs) of verklaringen (Saunders en Ibrahim en anderen) waarbij de dwang bestond uit een schending van artikel 3 EVRM, een schending van een ander onderdeel van artikel 6 EVRM of zware sancties op niet-meewerken werden gesteld. Zonder een van deze vormen van ongeoorloofde dwang kan geen sprake zijn van een schending van het nemo-teneturbeginsel. ${ }^{22}$ Deze uitwerking van een noodzakelijke voorwaarde voor een schending van het nemoteneturbeginsel voldoet niet als normering van (vele) digitale opsporingsbevoegdheden. Om die stelling te

20. EHRM 17 december 1996, NJ 1997, 699, m.nt. Kn, punt 4 (Saunders t. het Verenigd Koninkrijk). Zie uitvoerig D.A.G. van Toor, Het schuldige geheugen? (diss. Nijmegen), Deventer: Kluwer 2017, H. 7.2.

21. EHRM 29 juni 2007, appl. nos. $15809 / 02$ en 25624/02, par. 55 (O'Halloran \& Francis t. het Verenigd Koninkrijk). Zie over dit toetsingskader D.A.G. van Toor, Het schuldige geheugen? (diss. Nijmegen), Deventer: Kluwer 2017, H. p. 410-413.

22. EHRM 13 september 2016, appl. nos. 50541/08, 50571/08, 50573/08 en 40351/09 (Ibrahim e.a. t. het Verenigd Koninkrijk).
19. Vgl. Conclusie F.W. Bleichrodt, 13 oktober 2020, ECLI:NL:PHR: 2020:927, rn. 41 over de aard en mate van dwang. Vgl. Conclusie F.W. Bleichrodt, 13 oktober 2020, ECLI:NL:PHR:2020:927, rn. 46 over de aard van de informatie. 
onderbouwen, schets ik hieronder twee asymmetrische casus waarin klachten over schending van het nemoteneturbeginsel onder het huidige positieve recht zijn ingediend.

\subsection{De casus in Jalloh ${ }^{23}$}

Jalloh wordt op 29 oktober 1993 door politieagenten in burger geobserveerd. Tijdens deze observatie zien de agenten dat Jalloh tweemaal een klein plastic zakje uit zijn mond haalt en aan iemand overhandigt en daarvoor geld ontvangt. Het is niet verwonderlijk dat deze gedragingen aanleiding geven om Jalloh te verdenken van het verkopen van verdovende middelen. De agenten gaan dan ook over tot de arrestatie van Jalloh. Tijdens de arrestatie zien de agenten dat de verdachte de nog in zijn mond bevindende bolletjes inslikt. Blijkbaar waren dat de enige verdovende middelen die de verdachte bij zich droeg: een fouillering levert namelijk niets op.

Om het ingeslikte bewijs te kunnen verzamelen, beveelt de officier van justitie dat Jalloh in het ziekenhuis, onder medisch toezicht, een braakmiddel krijgt toegediend. De verdachte weigert het braakmiddel zelfstandig in te nemen, waarna de vier agenten Jalloh immobiliseren zodat de arts via een tube door de neus een zoutoplossing in de maag van de verdachte kan spuiten. Na deze 'behandeling' braakt Jalloh een bolletje uit met (welgeteld) 0.2182 gram cocaine. De op de hiervoor beschreven wijze van toediening van het braakmiddel wordt door het EHRM als onmenselijke en vernederende behandeling gecategoriseerd. Vervolgens stelt het EHRM enkel als algemeen principe vast dat het gebruiken van bewijs dat verkregen is door een schending van artikel 3 EVRM 'an issue' onder artikel 6 EVRM oplevert.

Uiteindelijk bewandelt het EHRM een andere route om de ongeoorloofdheid van de dwang in het licht van artikel 6 EVRM vast te stellen. Op grond van het Duitse strafprocesrecht (artikel 81a StPO) ${ }^{24}$ zijn alle lichamelijke ingrepen toegestaan die van belang zijn voor de vaststelling van het delict, mits de ingreep door een arts wordt uitgevoerd met gebruikmaking van de normale methoden van zijn wetenschap en bij afwezigheid van gezondheidsrisico's. Het toedienen van een braakmiddel is derhalve mogelijk omdat daarmee voor het strafproces

23. EHRM (GK) 11 juli 2006, NJ 2007, 226; appl. no. 54810/00 (Jalloh t. Duits/and)

24. '(1) Eine körperliche Untersuchung des Beschuldigten darf zur Feststellung von Tatsachen angeordnet werden, die für das Verfahren von Bedeutung sind. Zu diesem Zweck sind Entnahmen von Blutproben und andere körperliche Eingriffe, die von einem Arzt nach den Regeln der ärztlichen Kunst zu Untersuchungszwecken vorgenommen werden, ohne Einwilligung des Beschuldigten zulässig, wenn kein Nachteil für seine Gesundheit zu befürchten ist.

(2) Die Anordnung steht dem Richter, bei Gefährdung des Untersuchungserfolges durch Verzögerung auch der Staatsanwaltschaft und ihren Ermittlungspersonen ( $\$ 152$ des Gerichtsverfassungsgesetzes) zu. (3) Dem Beschuldigten entnommene Blutproben oder sonstige Körperzellen dürfen nur für Zwecke des der Entnahme zugrundeliegenden oder eines anderen anhängigen Strafverfahrens verwendet werden; sie sind unverzüglich zu vernichten, sobald sie hierfür nicht mehr erforderlich sind.' belangrijk bewijs wordt vergaard, mits de procedurele waarborgen worden gevolgd. De brutaliteit en lichamelijke dwang die in Falloh wordt gebruikt daargelaten, het niet volgen van die procedurele waarborgen is op zichzelf voldoende om ongeoorloofde dwang aan te nemen volgens het EHRM (bij de inzet van een normaliter geoorloofde opsporingsmethode). Omdat het door dwang verkregen bewijs tegen de verdachte wordt gebruikt, is sprake van een schending van het nemoteneturbeginsel. In deze zaak wordt dus in strijd met nationale recht brutaal en met grove lichamelijke dwang gehandeld - overigens zijn meerdere verdachten overleden na de toepassing van dezelfde bevoegdheid waarna een nationaal verbod is ingesteld ${ }^{25}$ - om, naar het later blijkt, doorslaggevend bewijs te verkrijgen.

\subsection{De casus in Cyber00726}

Hoe anders is dat in het in september 2015 gestarte onderzoek Cyber007. Centraal in dit onderzoek staan phishinghandelingen. Na enige tijd komen meerdere verdachten in beeld, maar de onderhavige zaak betreft slechts een van de leden van de criminele organisatie. Deze desbetreffende verdachte heeft onder andere emails verzonden, met headers van de ABN Amro Bank en de Rabobank, waarin aan potentiële slachtoffers de inloggegevens van hun internetbankierenaccount wordt gevraagd, bijvoorbeeld omdat de pinpas binnenkort zou verlopen en de gegevens noodzakelijk zijn voor het aanvragen van een nieuwe pinpas. Op 16 februari 2016 is de verdachte aangehouden op verdenking van overtreding van meerdere vermogensdelicten. Tijdens de aanhouding draagt de verdachte een smartphone bij zich die tijdens een fouillering in beslag wordt genomen. De politie schakelt snel en ziet de waarde van de elektronische gegevensdrager voor het cyberonderzoek: zij zet de smartphone in vliegtuigmodus zodat het niet mogelijk is op afstand toegang te verkrijgen tot de gegevens op de smartphone (om de gegevens te verwijderen).

Vervolgens vragen de verbalisanten de verdachte tijdens het verhoor meermaals zijn elektronische gegevensdrager te ontgrendelen, maar hij weigert telkens. Nadat de verdachte erop is gewezen dat wanneer hij niet meewerkt de elektronische gegevensdrager met gepast geweld zal worden ontgrendeld, blijft hij elke vorm van medewerking weigeren. Deze weigering leidt ertoe dat de verdachte wordt geboeid en dat zijn rechterduim, volgens het vonnis zonder geweld, op de vingerafdrukscanner is geplaatst. De elektronische gegevensdrager wordt hierdoor ontgrendeld. Daarmee verkrijgen de autoriteiten toegang tot de inhoud van de elektronische gegevensdrager. Analyse van de inhoud levert vol-

25. Het Bundesgerichtshof $(\mathrm{BGH}$, cassatierechter) heeft tot tweemaal toe een vrijspraak vernietigd voor de arts die het braakmiddel toediende dat een verdachte noodlottig werd, en de methode als onrechtmatig bestempeld ('brechmitteleinsatz ist menschenunwürdig') en elke arts die deze methode toepast met de dood als gevolg kan worden vervolgd voor dood door schuld. BGH 29 april 2010, 5 StR 18/10 en BGH 20 juni 2012, 5 StR 536/11.

26. Rb. Noord-Holland 28 februari 2019, ECLI:NL:RBNHO:2019:1568, Computerrecht 2019/94, m.nt. D.A.G. van Toor. 
doende bewijs op tegen de verdachte en tegen medeverdachten met betrekking tot meerdere strafbare feiten.

\subsection{Vergelijking}

Anders dan in Falloh leveren de gedragingen in Cyber007 geen schending van het nemo-teneturbeginsel op. Dit moge (intuitief) enige bevreemding wekken. In Falloh wordt veel lichamelijke dwang gebruikt - het met geweld, door vier agenten, vastpinnen van de verdachte zodat via zijn neus braakmiddel kan worden toegediend - terwijl weinig informatie wordt verkregen: namelijk dat de verdachte 0,2 gram cocaine in zijn bezit had. Er wordt bijvoorbeeld geen informatie gewonnen over de organisatie die in verdovende middelen handelt en waarvan, gezien de geringe hoeveelheid cocaine en het feit dat Jalloh bolletjes uitgeeft en geld aanneemt, de verdachte onderaan de ladder staat.

Bij de biometrische ontgrendeling van een elektronische gegevensdrager wordt slechts in zeer beperkte mate een inbreuk op de fysieke integriteit gemaakt, terwijl gigaof terabytes aan informatie wordt verkregen over de verdachte, over medeverdachten en over de criminele organisatie in zijn geheel. In die zin is de inhoud van een elektronische gegevensdrager de beste kroongetuige die de autoriteiten zich kunnen wensen: hij bezit alle (historische) informatie, alle contactgegevens, zonder dat sprake is van waarheidsgetrouwheidsdiscussies. ${ }^{27}$

Dat het EHRM in Falloh tot een schending van het nemo-teneturbeginsel komt, en de rechtbank NoordHolland bij een biometrische ontgrendeling niet, is te verklaren vanuit het means-based perspectief - de dwang in Falloh is significant hoger - maar biedt gezien de hoeveelheid verkregen informatie weinig rechtsbescherming. Dit vormt mijns inziens voldoende aanleiding het huidige toetsingskader ter discussie te stellen. De criteria zijn ongepast om los te laten op de situatie waarin geringe dwang wordt gebruikt maar waarbij wel veel informatie wordt verkregen. De vraag die moet worden gesteld, is of het onproblematisch is zoveel informatie over een persoon (en eigenlijk, via de chatlogs en emailberichten, ook over andere personen) te verkrijgen? ${ }^{28}$ Hierbij moet niet uit het oog worden verloren dat de verdachte gedwongen wordt de toegang tot deze informatie te verlenen.

Daarom overwegen Albers, Beekhuis, Taylor Parkins-Ozephius en ik dat de verdachte die zijn elektronische gegevensdrager moet ontgrendelen (inclusief de ontgrendeling middels een wachtwoord) aanspraak zou moeten kunnen maken op een vergelijkbare regeling als de kroongetuigenregeling (uit andere landen). D.A.G van Toor, W. Albers, C.M. Taylor Parkins-Ozephius \& T. Beekhuis, 'De ontgrendelplicht in rechtsvergelijkend perspectief (deel 1)', Computerrecht 2020/131; T. Beekhuis, C.M. Taylor Parkins-Ozephius, D.A.G. van Toor \& W. Albers, 'De ontgrendelplicht in rechtsvergelijkend perspectief (deel 2)', Computerrecht 2020/179.

28. Vgl. M. Lindemann \& D.A.G. van Toor, 'Protection of a Suspect's Privacy in Criminal Procedures: Does the Conceptual Approach of the German Federal Constitutional Court Make a Difference?', Ars Aequi 2018, 5, p. 376-384.

\section{Intermezzo: de ontwikkeling van de privacybescherming onder het Vierde Amendement als voorbeeld}

De discussie of de invulling van rechtsbeschermende waarborgen bij de normering van opsporingsbevoegdheden aanpassing behoeft vanwege inter alia de ontwikkeling van de techniek is niet nieuw. Om mijn standpunt - dat de normering van opsporing door het nemo-teneturbeginsel niet meer voldoet - te onderbouwen, zoek ik aansluiting bij de discussie in het Amerikaanse constitutionele recht die in de jaren twintig van de vorige eeuw is gestart. Die discussie vertoont dezelfde kenmerken als de hierboven gepresenteerde analyse: nieuwe technieken (vooral de uitvinding van de telefoon en het moderne gebruik van smartphones) leiden tot veranderde interpretatie van een grondrecht, in dit geval het Vierde Amendement bij de Amerikaanse Grondwet: het recht op bescherming van de privésfeer.

Daarnaast is de bescherming die het Vierde Amendement de verdachte biedt te vergelijken met het continentale nemo-teneturbeginsel, terwijl het Vijfde Amendement te vergelijken is met het zwijgrecht. Het Vierde Amendement verbiedt, onder bepaalde voorwaarden, opsporingshandelingen en is dus means-based, zoals ook het nemo-teneturbeginsel in de rechtspraak van het EHRM bescherming biedt tegen ongeoorloofde opsporingshandelingen. ${ }^{29}$ Het Vijfde Amendement verbiedt de gedwongen verkrijging van een bepaald type bewijs, namelijk hetgeen als testimonial is te categoriseren, en is dus material-based. Omdat zowel het Vierde Amendement als het nemo-teneturbeginsel de normering van tijdens de opsporing toegepaste middelen centraal stelt, is de discussie over de reikwijdte van het Vierde Amendement alsmede het gebruiken van de normering van rechten uit (kort gezegd) het privacycluster interessant voor de onderhavige problematiek.

De grondslag van de discussie is de interpretatie van de tekst van het Vierde Amendement ${ }^{30}$ bij de Amerikaanse Grondwet, waarbij een fundamenteel verschil van inzicht bestaat tussen het perspectief dat wordt ingenomen door textualists/originalists aan de ene kant en progressivists/modern liberalists aan de andere kant. Eigenlijk is de kern van het debat heel eenvoudig: in hoeverre mag de rechter de betekenis van de tekst, zoals vastge-

29. Zie uitvoerig D.A.G. van Toor, 'Het nemo-teneturbeginsel: rechtspraak van het Europese Hof voor de Rechten van de Mens en de Hoge Raad vergeleken', TBS\&H 2016, 1, p. 28-43. Zie ook E. Gritter, 'Het decryptiebevel aan de verdachte in het economisch strafrecht', TBS\&H 2017, 4, p. 192; J.S. Nan, 'Rechtspraak; nemo tenetur en de smartphone', TBS\&H 2019, 2, p. 116.

30. The right of the people to be secure in their persons, houses, papers, and effects, against unreasonable searches and seizures, shall not be violated, and no warrants shall issue, but upon probable cause, supported by oath or affirmation, and particularly describing the place to be searched, and the persons or things to be seized. 
steld door de Founding Fathers, uitleggen naar de omstandigheden van de huidige tijd? Textualists en originalists bepleiten de Amendementen te interpreteren naar de tekstuele betekenis ten tijde van de totstandkoming van de Grondwet en/of de tekst te interpreteren zoals van origine bedoeld door de Founding Fathers. In tegenstelling beargumenteren progressivists en modern liberalists juist de interpretatie van grondrechten naar de huidige stand der omstandigheden. Als de tekst van het Vierde Amendement wordt bekeken, wordt snel duidelijk waarom over de betekenis van dit Amendement veel discussie bestaat. Volgens het Vierde Amendement worden burgers beschermd in hun persoon, in hun huis, met betrekking tot hun documenten en persoonlijke bezittingen tegen onredelijke doorzoekingen en inbeslagnames. Van telefoontaps, gps-locatiebepaling of gegevens is daarin geen sprake.

Deze moderne opsporingsmethoden leiden tot veel discussie over de reikwijdte van het Vierde Amendement. ${ }^{31}$ Van oudsher was een physical trespass van privébezit een noodzakelijke voorwaarde om van een inbreuk op of een schending van het Vierde Amendement te kunnen spreken. ${ }^{32}$ Zo worden Olmsteadt en zijn handlangers (beruchte bootleggers in het noordwesten van de Verenigde Staten van Amerika) afgeluisterd in het bedrijfsgebouw dat zij gebruiken en via een tap van de telefoonlijn op publieke grond (dus voordat de lijn het privéterrein bereikt). Het Hooggerechtshof oordeelt dat hiermee geen inbreuk op verdachtes rechten wordt gemaakt omdat 'no trespass was committed upon any property of the defendants'. 33

Tegen deze vereenzelviging van eigendom en privacybescherming verzet Fustice Brandeis zich in zijn dissenting opinion. 'When the Fourth and Fifth Amendments were adopted, "the form that evil had theretofore taken," had been necessarily simple. Force and violence were then the only means known to man by which a Government could directly effect self-incrimination. It could compel the individual to testify - a compulsion effected, if need be, by torture. It could secure possession of his papers and other articles incident his private life - a to seizure effected, if need be, by breaking and entry. Protection against such invasion of "the sanctities of a man's home and the privacies of life" was provided in the Fourth and Fifth Amendments by specific language. Boyd v. United States, 116 U. S. 616, 630. But "time works

31. R.C. Power, 'Technology and the Fourth Amendment: A Proposed Formulation for Visual Searches', 80 J. Crim. L. \& Criminology 1 (1989-1990); O.S. Kerr, 'The Fourth Amendment and New Technologies: Constitutional Myths and the Case for Caution', 102 Mich. L. Rev. 801 (2004); C. Slobogin, 'Is the Fourth Amendment Relevant in a Technological Age?', Vanderbilt Public Law Research Paper No. 10-64, Vanderbilt Law and Economics Research Paper No. 10-56, Available at SSRN: https://ssrn.com/abstract=1734755 or http://dx.doi.org/ 10.2139/ssrn.1734755

32. Supreme Court of the United States of America 4 juni 1928, 277 U.S. 438 (Olmstead v. United States).

33. Supreme Court of the United States of America 4 juni 1928, 277 U.S. 438 (Olmstead v. United States), p. 438. changes, brings into existence new conditions and purposes." "34

In de jaren twintig leidt dit argument er nog niet toe dat het Hooggerechtshof omgaat, maar Brandeis' dissent is de opmaat voor het pleidooi van Harvey Schneider in Katz waarin het Hooggerechtshof de trespass doctrine verlaat. In zijn beroemde majority opinion in Katz overweegt Fustice Stewart dat 'the Fourth Amendment protects people, not places. (...) Thus, although a closely divided Court supposed in Olmstead that surveillance without any trespass and without the seizure of any material object fell outside the ambit of the Constitution, we have since departed from the narrow view on which that decision rested. ${ }^{35}$

Juist in deze discussie - over de reikwijdte van de protected areas op basis van het Vierde Amendement - kan dezelfde grond voor aanpassing van de normering van rechtsbeschermende waarborgen worden gevonden als die ik voorstel met betrekking tot de toetsing van digitale opsporingsbevoegdheden aan het nemo-teneturbeginsel. De huidige nemo-teneturnormering is ontwikkeld in de tijd dat, om met Brandeis te spreken, force and violence de gekozen methoden waren om de verdachte te dwingen belastend bewijs te produceren - denk aan de casus Falloh-, but time morks changes.

\section{De bescherming die het nemo-teneturbeginsel biedt}

Als startpunt voor die verandering worden in deze paragraaf verschillende perspectieven beschreven en geanalyseerd van de bescherming die het nemo-teneturbeginsel kan/moet bieden. Wat het nemo-teneturbeginsel precies omvat als protected area is namelijk voer voor discussie. Uit de rechtspraak en de literatuur kunnen in ieder geval de volgende aspecten worden gedistilleerd: (1) bescherming tegen het gebruik van ongeoorloofde dmang; ${ }^{36}$ (2) bescherming tegen een bepaalde vorm van medemerking; ${ }^{37}$ (3) bescherming tegen het gebruik van onder dwang verkregen informatie; ${ }^{38}$ en (4) bescherming tegen het wilsafhankelijk verkrijgen van informatie. ${ }^{39}$ Deze perspectieven worden hieronder nader toegelicht.

34. Supreme Court of the United States of America 4 juni 1928, 277 U.S. 438 (Olmstead v. United States), p. 473.

35. Supreme Court of the United States of America 18 december 1967, 398 U.S. 347 (Katz v. United States), p. 351, 353.

36. Zie uitgebreid D.A.G. van Toor, Het schuldige geheugen? (diss. Nijmegen), Deventer: Kluwer 2017, p. 390 e.v.

37. Zie bijv. M. Egberts \& W. Ferdinandusse, 'Reactie op Alex Bood', NJB 2019, 316; Commissie modernisering opsporingsonderzoek in het digitale tijdperk, Regulering van opsporingsbevoegdheden in een digitale omgeving, s.l. 2018, p. 105 e.v.

38. Zie bijv. ; Conclusie F.W. Bleichrodt, 13 oktober 2020, ECLI:NL:PHR: 2020:927, rn. 42-46; A. Bood, 'Geef ze een vinger ...', NJB 2018, 36, p. $2744-2748$.

39. Zie bijv. L. Stevens, 'Gedwongen biometrische toegangsverschaffing is niet in strijd met nemo tenetur', NJB 2019, 315, p. 401. 


\subsection{Bescherming tegen het gebruik van} ongeoorloofde dwang (means-based)

Een fundamenteel verschil tussen twee van de hierboven genoemde perspectieven betreft de discussie of het nemo-teneturbeginsel bescherming biedt tegen het gebruik van ongeoorloofde opsporingsmiddelen ter verkrijging van bewijs (in de Engelstalige literatuur wordt dit een means-based perspective genoemd $)^{40}$ of dat het nemo-teneturbeginsel bescherming biedt tegen de verkrijging van van de wil afhankelijk bestaand materiaal (material-based perspective). In het laatste geval zou het nemo-teneturbeginsel alleen bescherming bieden tegen de gedwongen creatie van bewijsmateriaal. Deze zeer selecte categorie van bewijsmiddelen omvat hetgeen de verdachte met zijn wil produceert. Het gaat dus meestal om het gesproken woord. ${ }^{41}$ Voor een groot deel is dat het terrein van het zwijgrecht, en mijns inziens biedt het nemo-teneturbeginsel een aanvullende bescherming. Die bescherming geldt voor alle soorten bewijsmiddelen en is afhankelijk van de wijze waarop het bewijs is verkregen. Ik zie de bescherming van het nemo-teneturbeginsel (in het positieve recht) dan ook als means-based.

Deze aanvullende bescherming komt duidelijk naar voren in de rechtspraak van het EHRM. In 2016 heeft de Grote Kamer van het EHRM het volgende overzicht opgesteld met betrekking tot ongeoorloofde dwang. Gezien het belang en de duidelijkheid van die overweging wordt die hier integraal weergegeven: 'The Court, through its case-law, has identified at least three kinds of situations which give rise to concerns as to improper compulsion in breach of Article 6. The first is where a suspect is obliged to testify under threat of sanctions and either testifies in consequence (see, for example, Saunders, cited above; and Brusco v. France, no. 1466/07, 14 October 2010) or is sanctioned for refusing to testify (see, for example, Heaney and McGuinness, cited above; and Weh v. Austria, no. 38544/97, 8 April 2004). The second is where physical or psychological pressure, often in the form of treatment which breaches Article 3 of the Convention, is applied to obtain real evidence or statements (see, for example, Jalloh, Magee and Gäfgen, all cited above). The third is where the authorities use subterfuge to elicit information that they were unable to obtain during questioning (see Allan v. the United Kingdom, no. 48539/99, ECHR 2002IX)' [onderstreping DvT]. ${ }^{42}$ Een vorm van ongeoorloofde dwang is een noodzakelijke voorwaarde voor een schending van het nemo-teneturbeginsel, ${ }^{43}$ waarbij het EHRM in de hierboven geciteerde overweging de drie voorbeelden op een rij heeft gezet die tot op

40. M. Redmayne, 'Rethinking the privilege against self-incrimination', Oxford Journal of Legal Studies 2007, 2, p. 223.

41. De gerechtvaardigde vraag is dan op welke wijze het nemo-teneturbeginsel van toegevoegde waarde is naast het zwijgrecht.

42. EHRM 13 september 2016, ECLI:CE:ECHR:2016:0913JUD005054108, par. 267 (Ibrahim e.a t. het Verenigd Koninkrijk).

43. Vgl. 'There is no room in the present case for applying the Fifth Amendment unless the Fourth Amendment was first violated.' Supreme Court of the United States of America 4 juni 1928, 277 U.S. 438 (Olmstead v. United States), p. 462 heden in de rechtspraak van het Hof als ongeoorloofde dwang zijn gecategoriseerd.

$\mathrm{Bij}$ het ontgrendelen van elektronische gegevensdragers zijn in deze visie, die volgens velen naar huidig recht de juiste interpretatie van de rechtspraak van het EHRM is, ${ }^{44}$ alleen de aard en mate van dwang die wordt toegepast tijdens de ontgrendelhandeling van belang. Het gaat dus om het vastpakken van de hand (of op andere wijze belemmeren van de bewegingsvrijheid van de hand) en het op de scanner leggen van een vinger. Aangezien die inbreuk op de lichamelijke integriteit als licht is te beschouwen, en absoluut niet de minimum level of severity overschrijdt die noodzakelijk is voor toepassing van artikel 3 EVRM, levert het gedwongen ontgrendelen met een biometrisch oogmerk naar huidig recht geen schending van het nemo-teneturbeginsel op. De verdachte wordt in dit perspectief dus alleen beschermd tegen opsporingshandelingen waarbij grof geschut - foltering, onmenselijke en vernederende behandeling, hoge sancties - wordt ingezet.

\subsection{Bescherming tegen een bepaalde vorm van medewerking}

Naast deze focus op de, in de woorden van het EHRM, improper compulsion kan de aard van de medewerking centraal worden gesteld. In de inleiding stelde ik al dat bij de verschillende perspectieven het vaak slechts om accentverschillen gaat, en dit is er daar een van. Waarbij in het hieraan voorafgaande perspectief de handeling van de autoriteiten centraal wordt gesteld - handelen zij geoorloofd? -, wordt bij het onderhavige perspectief de handeling van de verdachte als uitgangspunt genomen: welke soort handelingen mogen van de verdachte worden verlangd?

In verschillende publicaties over de ontgrendelplicht wordt de vorm van de medewerking van stal gehaald. Zo schrijven Egberts en Ferdinandusse dat '[i]n het strafrecht al lange tijd bij de toepassing van het nemo tenetur-beginsel een onderscheid [wordt] gemaakt tussen afgedwongen actieve medewerking door een verdachte en passieve medewerking'. ${ }^{45}$ Ook de Commissie focust haar advies onder andere op dit perspectief. ${ }^{46}$ Van de verdachte kan wel worden verlangd dat hij bepaalde handelingen moet dulden (de passieve 'medewerking'), maar de autoriteiten mogen hem niet dwingen zelf activiteiten te ontplooien. De Commissie verwoordt het als volgt: 'In het systeem van de Nederlandse wet wordt echter aangenomen dat vergelijkbare methoden die een meer of minder actieve vorm van medewerking vergen, zoals sorteerproeven, Oslo-confrontaties, schrijfproeven

44. Zie Conclusie F.W. Bleichrodt, 13 oktober 2020, ECLI:NL:PHR: 2020:927, rn. 29-41.

45. Zie bijv. M. Egberts \& W. Ferdinandusse, 'Reactie op Alex Bood', NJB 2019, 316.

46. Commissie modernisering opsporingsonderzoek in het digitale tijdperk, Regulering van opsporingsbevoegdheden in een digitale omgeving, s.l. 2018, p. 106 
en urineonderzoek verenigbaar zijn met het nemo tenetur-beginsel.' 47

Centraal staat dus in welke mate een actieve gedraging van de verdachte mag worden verlangd. De voorbeelden van de Commissie zijn niet volledig gelukkig gekozen. Bij een Osloconfrontatie gaat het om de identificatie van een persoon op basis van uiterlijk waarneembare fysieke kenmerken. Hierbij moet de verdachte zich 'presenteren', althans zichtbaar opstellen voor een getuige. Ook bij de sorteerproef gaat het om de identificatie van een persoon, maar dit keer op basis van geur. In beide gevallen hoeft hij niet actief bij te dragen aan de bewijsgaring, in de zin van dat hij een handeling moet verrichten of een intellectuele inspanning moet leveren waardoor bewijsmateriaal beschikbaar komt. Hij moet dulden dat hij wordt bekeken of besnuffeld. Het in laten scannen van een vingerafdruk is hiermee goed vergelijkbaar.

Bij een schrijfproef is dit anders: daarvoor dient hij een tekst te schrijven - en dat is zowel een actieve fysieke handeling als (eventueel) een intellectuele inspanning. Van een schrijfproef ten behoeve van een handschriftanalyse kan, doordat de verdachte activiteiten moet ontplooien, worden betwijfeld of dat verenigbaar is met het nemo-teneturbeginsel. ${ }^{48}$ Overigens is dit (natuurlijk) anders als de te vergelijken tekst in beslag wordt genomen tijdens een doorzoeking en niet ter plekke wordt geproduceerd.

Op de achtergrond speelt eigenlijk een andere discussie: niet de aard van de medewerking staat centraal, maar de door de medewerking verkregen informatie. Bij alle vormen van medewerking die als geoorloofd worden bestempeld, wordt materiaal verkregen dat onafhankelijk van de wil van de verdachte bestaat (zoals de vingerafdruk of de uiterlijk waarneembare fysieke kenmerken), ${ }^{49}$ terwijl de actieve medewerking veelal gelijk kan worden geschaald met het verkrijgen van materiaal dat afhankelijk van de wil bestaat (zoals een handschrift of het gesproken woord). Dat brengt mij tot het volgende perspectief.

\subsection{Bescherming tegen het gebruik van onder dwang verkregen informatie (material- based)}

Dat een bepaalde vorm van medewerking niet geoorloofd is of zou zijn, hangt in het onderhavige perspectief samen met welke soort informatie door de verdachte wordt geproduceerd. Als de verdachte enkel opsporingshandelingen zou moeten dulden, verzamelen de autoriteiten alleen bewijs dat onafhankelijk van de wil

47. Commissie modernisering opsporingsonderzoek in het digitale tijdperk, Regulering van opsporingsbevoegdheden in een digitale omgeving, s.l. 2018, p. 106.

48. D.A.G. van Toor, 'Het nemo-teneturbeginsel in de conceptwetsvoorstellen van het Wetboek van Strafvordering', TBS\&H 2018, 4, p. 249-254.

49. Vgl. Commissie modernisering opsporingsonderzoek in het digitale tijdperk, Regulering van opsporingsbevoegdheden in een digitale omgeving, s.l. 2018, p. 105 van de verdachte bestaat. Immers, van de verdachte wordt geen actieve handeling verlangd en hij dient niets met zijn wil te creëren. Hij en al het bestaand materiaal waartoe hij toegang kan verlenen, worden als object van onderzoek behandeld. Wanneer van de verdachte enige activiteit wordt verlangd, kan sprake zijn van het produceren van bewijsmateriaal dat afhankelijk van de wil van de verdachte bestaat. Hij is dan ook een subject: van hem wordt verlangd dat hij zijn cognitieve en/of fysieke capaciteiten aanwendt om materiaal te creëren.

Beide begrippen - actieve medewerking en materiaal dat afhankelijk van de wil bestaat - zijn echter geen synoniemen. Zo is het overhandigen van een sleutel voor een huis of het inscannen van een vingerafdruk een actieve handeling - die overigens ook als een dulden kan plaatsvinden, namelijk als de autoriteiten de sleutel in beslag nemen na een fouillering of de verdachtes hand pakken zodat de duim kan worden gescand -, waarmee de verdachte geen materiaal produceert dat nog niet bestaat. Zolang dat het geval is, is van een schending van het nemo-teneturbeginsel in het onderhavige perspectief geen sprake. Dit zou evenwel anders zijn in een volledig means-based perspectief: als de sleutel van verdachtes woning wordt verkregen doordat de verdachte de vindplaats van de sleutel prijsgeeft tijdens een marteling, dan zou het gebruik van de door de marteling gevonden bewijsmateriaal een schending van het nemo-teneturbeginsel opleveren. Bij een volledig material-based perspectief levert dit geen schending van het nemo-teneturbeginsel op omdat de verdachte de sleutel niet met zijn wil heeft gecreëerd.

In de onderhavige visie beschermt het nemo-teneturbeginsel dus de overdracht van materiaal dat de verdachte zelf, onder dwang, moet produceren. Het overdragen van al bestaand materiaal levert in dit perspectief geen schending van het nemo-teneturbeginsel op. Deze uitwerking van het nemo-teneturbeginsel is voornamelijk gebaseerd op het Saunders-arrest. ${ }^{50}$ Daarin wordt het volgende overwogen: 'the privilege against selfincrimination does not extend to the use in criminal proceedings of material which may be obtained from the accused through the use of compulsory powers but which has an existence independent of the will of the suspect such as, inter alia, documents acquired pursuant to a warrant, breath, blood, urine, hair or voice samples and bodily tissue for the purpose of DNA testing' [onderstreping DvT].

Bij het ontgrendelen met een biometrisch kenmerk wordt geen nieuw materiaal geproduceerd: de vingertop en de huid bestaan en kunnen, zonder schending van het nemo-teneturbeginsel, van de verdachte worden 'verkregen'. Dit is eventueel anders voor wachtwoorden: als het wachtwoord wordt verkregen doordat de

50. EHRM 17 december 1996, NJ 1997, 699 (Saunders t. het Verenigd Koninkrijk). Dit is mijns inziens een onjuiste uitleg van Saunders, zie D.A.G. van Toor, Het schuldige geheugen? (diss. Nijmegen), Deventer: Kluwer 2017, p. 370 e.v. 
verdachte wordt gedwongen het uit te spreken, dan produceert de verdachte materiaal. Dat is een schending van het zwijgrecht. Als de autoriteiten het wachtwoord op een andere manier verkrijgen, bijvoorbeeld door een vordering gegevens aan een telecommunicatiedienst of door een stuk papier waarop het wachtwoord is opgeschreven in beslag te nemen, is geen sprake van materiaal dat afhankelijk van de wil van de verdachte bestaat.

\subsection{Bescherming tegen het wilsafhankelijk verkrijgen van informatie}

Sommige auteurs leiden uit de rechtspraak van het EHRM af dat niet alleen de vraag of materiaal afhankelijk van de wil bestaat van belang is, maar ook of het materiaal afhankelijk van de wil van de verdachte kan worden verkregen. ${ }^{51}$ Stevens' analyse van de rechtspraak van het EHRM wordt door haar als volgt samengevat: 'Op basis van de rechtspraak van het EHRM geldt aan de ene kant van het spectrum dat het afdwingen (en het gebruik voor het bewijs) van wilsonafhankelijk materiaal - DNA, bloed, urine, bolletjes drugs, documenten - in beginsel geen strijd oplevert met het nemo tenetur-beginsel. ${ }^{52}$ Aan de andere kant van het spectrum geldt dat het afdwingen van verklaringen binnen een strafrechtelijke procedure, en het gebruik van buiten het strafproces afgedwongen verklaringen, in beginsel in strijd is met nemo tenetur. Het EHRM heeft het in dat verband over materiaal dat niet los van de wil van de verdachte kan worden verkregen. Tussen beide uitersten (wilsonafhankelijk materiaal versus verklaringen/wilsafhankelijk verkregen) zitten situaties waarin op het eerste gezicht wilsonafhankelijk materiaal toch afhankelijk van de wil van de verdachte wordt verkregen.' 53

Volgens Stevens is pas sprake van een schending van het nemo-teneturbeginsel als de verdachte materiaal - zowel materiaal dat onafhankelijk als materiaal dat afhankelijk van de wil bestaat $-{ }^{54}$ moet erkennen, ordenen of interpreteren. De enkele productie van materiaal dat afhankelijk van de wil bestaat, ${ }^{55}$ valt volgens haar buiten het bestek van de bescherming van het beginsel. Het gaat dus niet om de aard van het materiaal, maar om de aard van de medewerking (en dat is iets anders dan de

51. Zie bijv. L. Stevens, 'Gedwongen biometrische toegangsverschaffing is niet in strijd met nemo tenetur', NJB 2019, 315, p. 401.

52. Zie hier en in de volgende zin een material-based interpretatie, waarbij de frase 'in beginsel' hoogstwaarschijnlijk ruimte biedt om die te combineren met een means-based perspectief.

53. L. Stevens, 'Gedwongen biometrische toegangsverschaffing is niet in strijd met nemo tenetur', NJB 2019, 315, p. 401.

54. L. Stevens, 'Gedwongen biometrische toegangsverschaffing is niet in strijd met nemo tenetur', NJB 2019, 315, p. 403

55. Stevens gebruikt een andere definitie van wilsafhankelijk materiaal: 'Mijn stelling is kortom, dat uit de Europese rechtspraak volgt dat 1. de mate en aard van de dwang, in relatie tot 2 . de (daardoor bewerkstelligde) aard van de medewerking van de (huidige of toekomstige) verdachte, mede bepalend zijn voor 3 . de aard van de informatie in de zin van het onderscheid "wilsonafhankelijk materiaal" (bijvoorbeeld bankafschriften) of "wilsafhankelijk materiaal" (een erkenning, ordening, interpretatie van bankafschriften).' L. Stevens, 'Gedwongen biometrische toegangsverschaffing is niet in strijd met nemo tenetur', NJB 2019, 315, p. 401. 'simpele' dichotomie tussen dulden en actief meewerken) en de mate en aard van dwang die bepalen of sprake is van wilsafhankelijk verkrijgen van informatie. ${ }^{56}$

In dit perspectief levert het gedwongen scannen van een vingerafdruk ook geen schending van het nemo-teneturbeginsel op. Omdat de medewerking passief is en de verdachte geen vervolghandeling verricht, in de zin van het ordenen of interpreteren van de op de gegevensdrager aangetroffen informatie, ${ }^{57}$ wordt hij niet gedwongen zichzelf te incrimineren.

\subsection{Afronding}

Gezien de conclusie uit de vorige subparagraaf kan nogmaals worden gesteld dat het vooral om accentverschillen in de bescherming gaat - immers bij alle perspectieven is biometrische ontgrendeling geoorloofd -, die vooral van belang is voor het bepalen van de reikwijdte van de bescherming ten opzichte van materiaal dat onafhankelijk van de wil van de verdachte bestaat. ${ }^{58}$ De geringste bescherming vindt plaats bij het materialbased perspectief. $\mathrm{Bij}$ dit perspectief is geen ruimte voor de bescherming tegen de gedwongen vergaring van materiaal dat onafhankelijk van de wil bestaat. In de andere perspectieven is de reikwijdte met betrekking tot de gedwongen vergaring van materiaal dat onafhankelijk van de wil bestaat afhankelijk van (1) de vorm van de medewerking; en/of (2) de toegepaste dwang; en/of (3) of de aard van de verkrijging. Uit de verschillende perspectieven blijkt in ieder geval dat zowel de bron/ oorsprong/aard (van de verkrijging) van de informatie - bestaat de informatie afhankelijk van de wil van de verdachte c.q. kan de informatie onafhankelijk van de wil van verdachte worden verkregen? - als de toegepaste dwang van invloed zijn op de beoordeling van klachten over de schending van het nemo-teneturbeginsel. De hoeveelheid verkregen informatie en de inhoud van de informatie zijn dat niet. Juist die punten verschillen in 'moderne' nemo-teneturzaken ten opzichte van de 'traditionele' zaken.

\section{Discussie en conclusie: fundamentele bezinning van de normering van het opsporingsonderzoek in een digitale context}

Het is nooit genoeg: telkens weer wordt gepleit voor uitbreiding van het opsporingsinstrumentarium (en die

56. L. Stevens, 'Gedwongen biometrische toegangsverschaffing is niet in strijd met nemo tenetur', NJB 2019, 315, p. 401, 403.

57. Het analyseren van data en daarover conclusies presenteren, is wel een handeling waarmee sprake is van het wilsafhankelijk verkrijgen van informatie. CBb 5 juli 2019, ECLI:NL:CBB:2019:177, r.o. 5.3.7.

58. De bescherming van materiaal dat afhankelijk van de wil bestaat, zou mijns inziens via het zwijgrecht moeten lopen. 
lokroep wordt door de wetgever vaak zonder nauwkeurige analyse gehonoreerd) ${ }^{59} \mathrm{Zo}$ ook tijdens de modernisering van het Wetboek van Strafvordering: een meer fundamentele bezinning op de regeling van het opsporingsonderzoek in een digitale context is klaarblijkelijk noodzakelijk voor een snelle en wendbare opsporing. ${ }^{60}$ Dit gaat zelden tot nooit gepaard met een roep tot bezinning over de normering van het opsporingsonderzoek (anders dan de precieze toepassingsvoorwaarden voor de nieuwe bevoegdheden). Dat moge (ten minste enige) verwondering wekken: de strafvordering is zowel rechtsbeschermend als instrumenteel. ${ }^{61}$ Beide maken deel uit van een relationeel rechtsbegrip, omdat het rechtsbetrekkingen en machtsverhoudingen beheert, en probeert te voorkomen dat een van beide elementen dominant wordt. ${ }^{62}$ Als een fundamentele bezinning op de regeling van het digitale opsporingsonderzoek klaarblijkelijk noodzakelijk is, ligt ook een fundamentele bezinning op de normering van datzelfde opsporingsonderzoek voor de hand.

Daartoe is de wetgever echter niet overgegaan. De Commissie en de wetgever gebruiken de bestaande rechtsbeschermende waarborgen - uit het tijdperk van de rule of force - voor de normering van de (nieuwe) digitale bevoegdheden. Bij de ontgrendelplicht van elektronische gegevensdragers leidt dit tot een onwenselijke uitkomst: de criteria die stammen uit de tijd dat force and violence werd toegepast om bewijs te verzamelen, kunnen niet analoog worden toegepast op de situatie waarin een enkele druk op de knop giga- of terabytes aan informatie oplevert. Maar, hoe nu verder?

\subsection{Naar een holistische benadering van privacy- inbreuken en het nemo-teneturbeginsel: een echt means-based perspectief}

Een mogelijke optie, die hierboven voorzichtig in de week is gelegd, is een meer holistische benadering van het concept ongeoorloofde dwang. In de rechtspraak en in de literatuur staat de dwang waarmee de informatie van de verdachte wordt afgedwongen en welke aard of vorm van medemerking dan wordt verlangd veelvuldig centraal. Deze perspectieven worden echter beperkt uitgelegd: in de rechtspraak van het EHRM zijn sancties, schendingen van artikel 3 EVRM en schendingen van andere artikel 6 EVRM-rechten de enige geaccepteerde vormen van ongeoorloofde dwang. De dwang moet dus aan een bepaalde categorie voldoen, om in aanmerking

59. D. van Toor, 'Het doel heiligt het middel? Over de noodzaak van uniforme criteria voor evaluatie van de effectiviteit en efficiëntie van de opsporing', Proces 2015, 4, p. 229-239.

60. Commissie modernisering opsporingsonderzoek in het digitale tijdperk, Regulering van opsporingsbevoegdheden in een digitale omgeving, s.l. 2018, p. 7.

61. R. Foqué \& A.C. 't Hart, Instrumentaliteit en rechtsbescherming, Arnhem: Gouda Quint 1990, p. 15.

62. S. Gutwirth \& P. de Hert, 'Grondslagentheoretische variaties op de grens tussen het strafrecht en het burgerlijk recht', in: K. Boonen, C.P.M. Cleiren, R. Foqué \& Th.A. de Roos (red.), De weging van 't Hart: Idealen, waarden en taken van het strafrecht, Deventer: Kluwer 2002, p. 124 te komen voor een schending van het nemo-teneturbeginsel.

Natuurlijk geeft dit meer rechtszekerheid dan een meer casuïstische, holistische benadering waarin ad hoc wordt bekeken of de dwang geoorloofd is, mede in het licht van de gevraagde medewerking en de aard en hoeveelheid informatie die wordt verkregen. Gezien de verandering in de opsporing voel ik er toch veel voor om het hokjes-denken los te laten. De categorisatie die nu ten grondslag ligt aan schendingen van het nemo-teneturbeginsel past niet bij de zeer geringe dwang die wordt toegepast bij digitale opsporingsbevoegdheden. Bij digitale opsporing is fysiek geweld zelden noodzakelijk - digitaal fysiek geweld is zelfs een contradictio in terminis - terwijl de meeste bevoegdheden heimelijk worden ingezet - en er dus ook geen aangekondigde sanctie aan ten grondslag ligt. De dwang die wordt toegepast, is dus fundamenteel anders dan in de landmark cases, zoals Saunders, Falloh en Ibrahim en anderen. Ook de verkregen informatie is veranderd: niet langer wordt de verdachte gedwongen te praten, enkele documenten te overhandigen of drugs te braken, maar worden alle toegankelijke gegevens verzameld en vervolgens (geautomatiseerd) geanalyseerd. ${ }^{63} \mathrm{Bij}$ de vergaring wordt geen enkel strafvorderlijk relevant onderscheid gemaakt: van enige doelbinding van de vergaring van alle informatie is geen sprake. Het ontgrendelen van een elektronische gegevensdrager om vervolgens alle informatie te kunnen analyseren, is vergelijkbaar met het in beslag nemen van de complete inboedel tijdens een doorzoeking. Dat laatste zou naar huidig recht niet door de beugel kunnen. Waarom laten we dan wel toe dat de onverzadigbare datahonger van de autoriteiten leidt tot ongelimiteerde vergaring van gegevens om later te analyseren welke gegevens relevant zijn?

Als de hierboven genoemde veranderingen - de lichte dwang en de stroom aan gegevens - als uitgangspunt worden genomen, moet ook de oplossing daar worden gezocht. De eerste stap is dat de uitwerking van de ongeoorloofde dwang moet worden losgelaten. Hetzelfde geldt voor de dichotomie van dulden en actief meewerken (waarbij ik het verder onbesproken laat of, en in hoeverre, die dichotomie daadwerkelijk voorkomt in de rechtspraak). Een criterium dat betrekking heeft op de verkregen informatie moet worden toegevoegd en centraal worden gesteld, waarbij aansluiting kan worden gezocht bij doctrines over de bescherming van gegevens onder het recht op respect voor privacy, zoals de Duitse

63. Mogelijk zou dit ook in strijd zijn met de eis van proportionaliteit (die na de modernisering van het Wetboek van Strafvordering een wettelijke basis krijgt), maar ik voel meer voor de hoeveelheid informatie als algemene norm die is losgekoppeld van de ernst van het strafbare feit. Bij lichte vergrijpen, kan de hoeveelheid informatie via de proportionaliteit beperkend werken, maar bij de ernstigste strafbare feiten is het de vraag of de proportionaliteit een zinvolle beperking van overheidsmacht is. 
absoluter Kernbereich ${ }^{64}$ of de bescherming naar hoeveelheid en gevoeligheid van de informatie. ${ }^{65}$

Tegen deze toevoeging kan worden tegengeworpen dat artikelen 6 en 8 EVRM, althans het nemo-teneturbeginsel en het recht op respect voor privacy, op een hoop worden gegooid, terwijl het twee afzonderlijke rechten zijn. Het verband tussen privacy en het nemo-teneturbeginsel is, als het nemo-teneturbeginsel wordt gezien als mogelijkheid om informatie geheim te houden, theoretisch enger dan verwacht. Juist theorieën zoals priva$c y$-as-secrecy en privacy als controle over persoonlijke informatie spelen een centrale rol in het rechtstheoretische debat over de reikwijdte van het recht op respect voor privacy. ${ }^{66}$

Het nemo-teneturbeginsel beschermt de verdachte tegen ongeoorloofde opsporingshandelingen waardoor hij zelf bewijsmateriaal produceert, openbaart, erkent of overhandigt, in aanvulling op het zwijgrecht. In de kern gaat het eerstens om zelfstandig en onafhankelijke keuzes te kunnen maken. Maar nog meer biedt het nemoteneturbeginsel bescherming tegen het produceren, openbaren, erkennen of overhandigen van persoonlijke, potentieel incriminerende, informatie. Het nemo-teneturbeginsel maakt het mogelijk dat burgers die als verdachte worden aangemerkt informatie geheimhouden van de almachtige overheid. De verdachte zou zelf de controle moeten kunnen uitoefenen over (bepaalde) handelingen, zoals het erkennen of overhandigen, met betrekking tot persoonlijke informatie.

Als de mogelijkheid tot het geheimhouden van informatie centraal wordt gesteld - waarbij ik niet bedoel dat de verdachte de volledige controle over het openbaar maken van informatie moet verkrijgen -, bestaat geen betekenisvol verschil tussen vingerafdrukken en wachtwoorden in de context van versleutelde gegevensdragers en het nemo-teneturbeginsel; beide methoden zorgen ervoor dat privé-informatie ontoegankelijk is voor derden. Het doel is de bescherming van die informatie, daarom zou bij de toetsing van een eventuele schending van het nemo-teneturbeginsel rekening moeten worden gehouden met de hoeveelheid en inhoud van de verkregen informatie (waarmee ik niet de potentieel incriminerende inhoud bedoel, maar de relevantie van die inhoud voor de persoonlijke levenssfeer), en niet met de ontgrendelmethode. ${ }^{67}$ Het gaat dus niet om de means, maar om het end, waarbij niet geldt dat het doel het middel heiligt. In de zin van de bescherming van privéinformatie zijn juridische verschillen tussen biometri-

64. Zie bijv. BGH, 10 augustus 2005, Az. 1 StR 140/05; M. Lindemann \& D.A.G. van Toor, 'Protection of a Suspect's Privacy in Criminal Procedures: Does the Conceptual Approach of the German Federal Constitutional Court Make a Difference?', Ars Aequi 2018, 5, p. 376-384.

65. Zie uitvoerig D.A.G. van Toor, Het schuldige geheugen? (diss. Nijmegen), Deventer: Kluwer 2017, p. 321 e.v.

66. Zie uitvoerig D.A.G. van Toor, Het schuldige geheugen? (diss. Nijmegen), Deventer: Kluwer 2017, p. 215-226.

67. Dit maakt het gebruik van een vingerafdruk ter identificatie anders dan het gebruik van een vingerafdruk om gigantische hoeveelheden gevoelige gegevens te vergaren. sche kenmerken en wachtwoorden die leiden tot verschillende uitkomsten in functioneel vergelijkbaar situaties ongewenst.

Tot slot, is 'the claim that compelled self-incrimination is an improper and impermissible invasion of a person's right to privacy one of the most popular justifications for the privilege against self-incrimination'. ${ }^{68}$ Aan het bestaansrecht van het nemo-teneturbeginsel wordt in de Amerikaanse literatuur sterk getwijfeld, en vele auteurs vinden geen overtuigende rechtsgrond voor het nemoteneturbeginsel, ${ }^{69}$ maar die wordt door sommige wel gevonden in het feit dat het nemo-teneturbeginsel ook privacydoeleinden dient. ${ }^{70}$ De meeste, zo niet alle, opsporingshandelingen maken een inbreuk op het recht op respect voor privacy, omdat daarmee vrijwel altijd informatie over de verdachte wordt verzameld. Het ligt daarmee voor de hand om de privacy-inbreukmakende opsporingshandelingen te zien als een mean waartegen het nemo-teneturbeginsel bescherming dient te bieden. In de Verenigde Staten van Amerika vinden daarom dezelfde oproepen plaats: het Hooggerechtshof zou afstand moeten nemen van de dichotomie physical evidence - niet beschermd onder het Vijfde Amendement tegenover testimonial evidence - wel beschermd onder het Vijfde Amendement - bij de uitleg van het nemoteneturbeginsel, ${ }^{71,72}$ en de bescherming van privé-informatie centraal moeten stellen.

\subsection{Afronding}

Het oordeel van de rechtbank Noord-Holland - dat het gedwongen ontgrendelen van elektronische gegevensdragers niet in strijd is met het nemo-teneturbeginsel getuigt volgens Bleichrodt niet van een onjuiste rechtsopvatting. ${ }^{73}$ Slechts een auteur overwoog anders, ${ }^{74}$ terwijl velen tot dezelfde conclusie als de rechtbank Noord-Holland kwamen. ${ }^{75}$ Die analyse van het positieve

68. D. Dolinko, 'Is there a Rationale for the Privilege against Self-Incrimination', UCLA L. Rev. 1986, 4, p. 1107.

69. D. Dolinko, 'Is there a Rationale for the Privilege against Self-Incrimination', UCLA L. Rev. 1986, 4, p. 1064; R.J. Allen, 'Theorizing about SelfIncrimination', Cardozo L. Rev. 2008, 3, p. 729.

70. H. Metz, "'Your Device is Disabled": How and Why Compulsion of Biometrics to Unlock Devices Should be Protected by the Fifth Amendment Privilege', 53 Val. U. L. Rev. 427 (2019); E. Lemus, 'When Fingerprints Are Key: Reinstating Privacy to the Privilege Against Self-Incrimination in Light of Fingerprint Encryption in Smartphones', 70 SMU L. Rev. 533 (2017), p. 554; V. Mohan \& J. Villasenor, 'Decrypting the Fifth Amendment: The Limits of Self-Incrimination in the Digital Era', 15 U. Pa. J. Const. L. Height. Scrutiny 11 (2012).

71. E. Lemus, 'When Fingerprints Are Key: Reinstating Privacy to the Privilege Against Self-Incrimination in Light of Fingerprint Encryption in Smartphones', 70 SMU L. Rev. 533 (2017), p. 554; V. Mohan \& J. Villasenor, 'Decrypting the Fifth Amendment: The Limits of Self-Incrimination in the Digital Era', 15 U. Pa. J. Const. L. Height. Scrutiny 11 (2012), p. 11: "the question of what constitutes a "testimonial act" must be revisited to proactively ensure that the Fifth Amendment privilege against self-incrimination is not eviscerated by emerging technologies.

72. Dit is dus een zeer sterk material-based perspectief.

73. Conclusie F.W. Bleichrodt, 13 oktober 2020, ECLI:NL:PHR:2020:927.

74. A. Bood, 'Geef ze een vinger ...', NJB 2018, 36, p. 2744-2748.

75. D.A.G. van Toor, 'De vergrendelde smartphone als object van strafvorderlijk onderzoek', Computerrecht 2017, 1, p. 3-11; D.A.G. van Toor, 'Het gedwongen ontgrendelen van een smartphone in het licht van het 
recht vind ik nog steeds overtuigend, maar niet langer wenselijk. De schoen wringt mijns inziens bij de toepassing van aloude criteria op moderne situaties: bij het nemo-teneturbeginsel leidt dit tot situaties dat de autoriteiten hun datahonger kunnen stillen wanneer zij slechts lichte dwang toepassen. De focus op de aard en mate van dwang als centraal criterium bij de beoordeling van nemo-teneturklachten moet plaatsmaken voor een meer op de informatie gebaseerd toetsingskader. Niet het ingezette middel, de handeling van de autoriteiten - daar gaat het om bij het criterium de aard en mate van dwang -, maar het doel - de verzameling informatie moet bepalend zijn. 